\title{
超微粒子を用いたセラミックスの接合
}

\author{
近藤均・ 川村裕明・稲川幸之助・伊藤 昭夫 ・ 阿部 哲也* ・村上 義夫* \\ 日本真空技術(株)超材料研究所 $\mathbf{T} 289-12$ 千葉県山武郡山武町横田 523 \\ *日本原子小研究所 T311-02 茨城県那场郡那坷町大字向!1 801-1
}

(1987 年 7 月 4 日受理)

\section{Ceramics Bonding by Using Ultrafine Particles}

\author{
Hitoshi KONDOH, Hiroaki KAWAMURA, Kounosuke INAGAWA, \\ Akio ITOH, Tetsuya ABE* and Yoshio MURAKAMI* \\ Institute for Super Materials, ULVAC Corporation \\ 523 Yokota, Sanbu-cho, Sanbu-gun, Chiba 289-12 \\ * Japan Atomic Energy Research Institute \\ 801-1 Ooazamukaiyama, Naka-machi, Ibaraki-ken 311-02
}

(Received July 4, 1987)

\begin{abstract}
A technique for ceramics bonding was developed by using ULTRAFINE PARTICLES (UFP) which makes the ceramic surface smooth and increases the contact area of the surface. The technique enabled the solid-state bonding of ceramics to metals or ceramics to ceramics to be achieved at lower temperature and pressures compared with those in conventional methods. $\mathrm{Al}_{2} \mathrm{O}_{3}$ was bonded to SUS 304 at a temperature of $1200^{\circ} \mathrm{C}$ with a layer of Nb UFP, prepared by the gas evaporation method. The tensile strength of the bonded specimen was $46 \mathrm{MPa}$. Si3 $\mathrm{N}_{4}$ ceramic was also bonded to $\mathrm{Si}_{3} \mathrm{~N}_{4}$ ceramic at a temperature of $1500^{\circ} \mathrm{C}$ and a pressure of $15 \mathrm{MPa}$ with the $\mathrm{Si}_{3} \mathrm{~N}_{4} \mathrm{UFP}$ layer. The tensile strength of the bonded specimen was $70 \mathrm{MPa}$, and the value was five times as large as that of the bonded specimen without the UFP layer.
\end{abstract}

\section{1.はじめに}

セラミックスは耐熱性, 耐摩耗性, 耐食性などの点で 優れた特性を有する反面, 脆く, 加工性が悪いという欠 点を持っている。そのため大型複雑形状のあのを作製す るのが闲難であり，七ラミックスの利用範用を薯しく狭 くしている。こうした欠点を克服し，セラミックスを広 範囲に使用するためには，小型単純形状のものを複数つ なぎ合せて所望の形状とする“セラミックス同志の接命 技術”あるいは必要な部分のみを金属からセラミックス に犆きかえる“金属之セラミックスの挍合技術”の開発 が急務である。

セラミックスの掞合方法として現在有菂視されている のは，万う接法と固相接合法である。万う接法は液体金 属あるいはガラスなどの酸化物をろう材として母材間に 挿入して，加熱する力法である。この力法では母材閂の 接触がろうとの机によって保持されるので, 好性を
よくするための工夫が必要である”。それには，セラミ ックス表面をメタライズ処理する ${ }^{2)}$ とか, Ti などの活 性金属をろうに添加する3) などの方法がとられている。 耐熱性等は用いるろうの物性に支配され，一般に母材よ りは少っている。固相接合法は母材同志を直接接触させ て稀と温度を加えることによって固相拡散させるす法 である。この方法は母材間に異種物質が介在していない ので，线材に匹敵する強度や耐熱性を得ること屯可能で ある ${ }^{4)}$ 。その反面, 有効に固相拡散を行うためには，母 材間の接触面積を大きくすることが不可欠であり，その ために HIP 等の装置を用いる必要があり5)，コストが 高くなるという欠点がある。

筆者らは，固相接合の持つ利点を生かしながら，その 欠点を克服する手段として，母材間に超微粒子（粒径 $10 \mathrm{~nm}$ 程度）から成る層を挿入する方法を見出した。乙 こでは, アルミナと SUS 304 の接合への応用例を中心 に述べささらに窒化ケイ素同志の接合についても簡単に 
ふれる。

\section{2. 基本的な考え方}

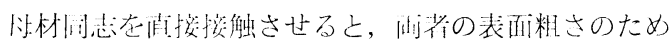
に除間が生じ，そのままでは揬触面積は極めて小さい。 従来の固相接合では，高温下で加圧することによって両 者を変形させ，強制的に接触面積を增やす方法がとられ ている。この際，标材の一方または耐方がセラミックス の㙚合には変形させるのに高いた力（通常 $100 \mathrm{MPa}$ 程

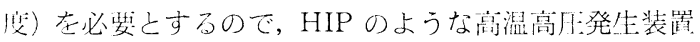
在用いなけ机ばならない。母材間に泪者の表面粗さに比 して䒧分に小さい粒径を持つ超微粒子を插入すれば，表 再粗さに起因する隙間を埋め，接触面積を増やすことが

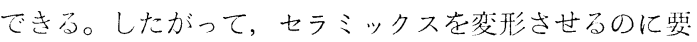
するような高无を必要とせず，従来法より低圧で接合で きると考えられる。さらに超微粒子の活性を利用するこ 上によって，処理鼬度老低くできる可能性もむる。

\section{3. アルミナと SUS 304 の接合への応用}

\section{1 実験方法}

作製した接合体の断面図を Fig.1に示す。全体の形状 は引張強度武験に適したものとした。アルミナ $\left(\mathrm{Al}_{2} \mathrm{O}_{3}\right)$ は純度 $99.5 \%$ の焼結 体で，接合面を $R_{\mathrm{a}}=0.5 \sim 1 \mu \mathrm{m}$ $\left(R_{\mathrm{m}: \mathrm{x}}=4 \sim 8 \mu \mathrm{m}\right)$ 程度となるように研磨した。超微粒子 (UFP) 萿はガス中竟発法 ${ }^{6,7)}$ によって生成した UFPを その場で $\mathrm{Al}_{2} \mathrm{O}_{3}$ 表面に堆積させる方法で形成した。用 いるUFP には酸素と結合しやすい金属, たとえば, $\mathrm{Ti}, \mathrm{Zr}, \mathrm{Nb}$ 等がよいと考えられるが，熱膨張係数や忍 緩和材との組み合わせ等を考慮して $\mathrm{Nb}$ を選んだ。 忘力緩和材は $\mathrm{Al}_{2} \mathrm{O}_{3}$ と SUS 304 の熱膨張係数差 $\left(\mathrm{Al}_{2} \mathrm{O}_{3}\right.$

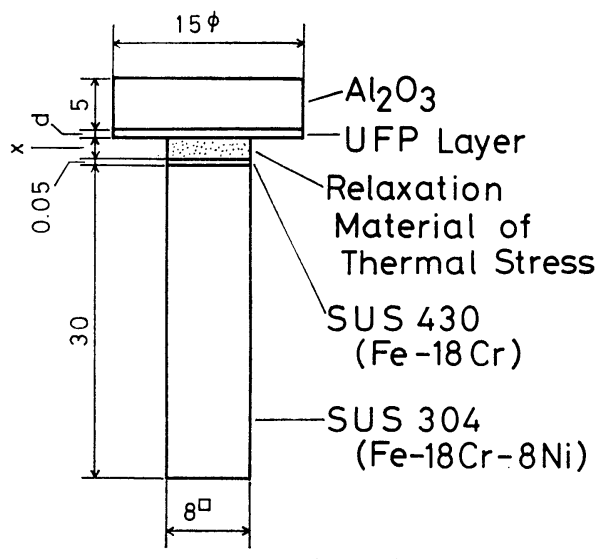

$(\mathrm{mm})$

Fig. 1 Cross-sectional view of bonded specimen.
が $8.1 \times 10^{-6} \mathrm{~K}^{-1}$, SUS 304 が $\left.17.3 \times 10^{-6} \mathrm{~K}^{-1}\right)$ によっ て生じる残留応力を緩利するためのもので， $\mathrm{Nb}$ 単層あ るいは $\mathrm{Nb} / \mathrm{Mo}$ の積層とした。厚さは 0 から $2 \mathrm{~mm}$ と した。 $\mathrm{Nb}$ は熱膨張係数が $\mathrm{Al}_{2} \mathrm{O}_{3}$ とほぼ等しく, Moは それより小さい。们限要素法による内部圭うの訃算結果 から上記の組み合わせが応力緩和材として適していると いう報告があり ${ }^{8)}$ ，本実験においてもそれを採用した。 SUS 430 は $\mathrm{Nb}$ と $\mathrm{Ni}$ (SUS 304 に含まれる) の共昆 反応を防バ目的で挿入した。应さは $50 \mu \mathrm{m}$ とした。 $\mathrm{Nb}$ は Fe あるいは $\mathrm{Cr}$ とも其鼠反忍を起こすが，本実験の 処理条件下 $\left(1250^{\circ} \mathrm{C}\right.$ 以下)では考虑する必要はない。用い た金属材料はいずれも接合面を 1500 番のエメリーベー パーで研磨した。冬供武材を㲸のごとく重极䍱わせたの ち，ホットプレス処理することによって接合体を得た。

$\mathrm{Al}_{2} \mathrm{O}_{3}$ の表面に $\mathrm{Nb}$ UFP 層を形成するための装置の 概略図を Fig. 2 亿示す。苹压 $10 \mathrm{k} \sim 20 \mathrm{kPa}$ の $\mathrm{Ar}+$ $\mathrm{H}_{2}$ 混合ガス中でタングステン電極と原料 $\mathrm{Nb}$ 間にア一 ク放電を発生させることによって，Nb UFP を発生さ せた。Nb UFP はプラズマフレームに乗って指向性の よい流れを作り，対向した $\mathrm{Al}_{2} \mathrm{O}_{3}$ 基板上に付着堆積す る。 $\mathrm{Al}_{2} \mathrm{O}_{3}$ 基板は主としてプラズマフレームによって加 熟され, UFP 堆積中一定温度に保持さ机る。UFP 束の 断面積はプラズマフレームのそれより大きいため, 蒸発 源の温度が一定の時，基板位置を上下させることによっ て，UFP の堆秥速度を変えることなく基板温度を変え ることができた。UFP の堆積速度の制御は， $\mathrm{H}_{2}$ 分圧も しくはアーク放笔出力を变化させることにより行った。 以上の組み命わせによって，任意の堆積速度及び基板温 度を得ることができた。

Nb UFP の代表的な TEM 像を Fig. 3 亿示す。これ

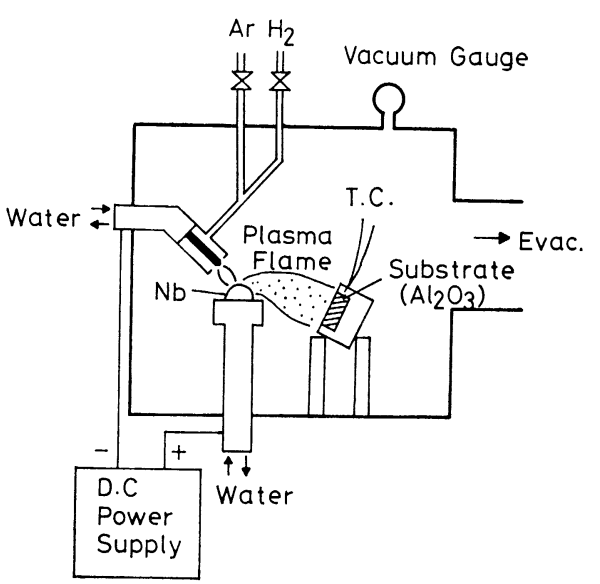

Fig. 2 Schematic diagram of the apparatus for $\mathrm{Nb}$ UFP layer preparation. 

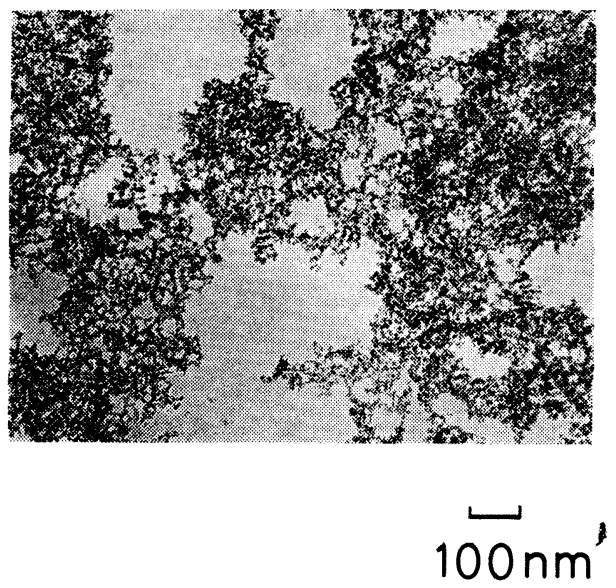

Fig. 3 Transmission electron micrograph of typical $\mathrm{Nb}$ UFP. $P_{\mathrm{T}}=14 \mathrm{kPa}, Q_{\mathrm{H}_{2} / \mathrm{Ar}}=0.4$

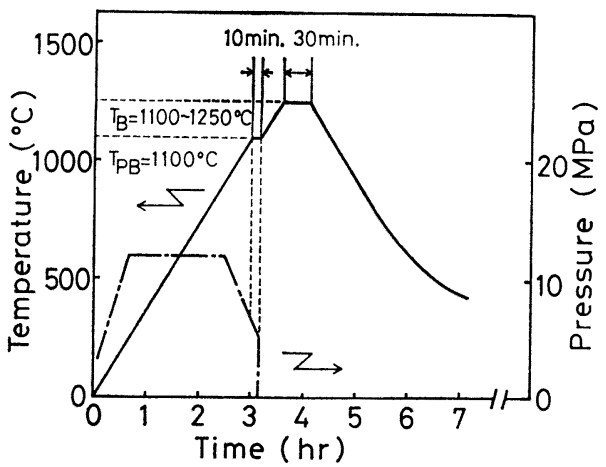

Fig. 4 Diagram illustrating the variation of temperature and pressure in hot-pressing.

は Fig. 2 の装置で $\mathrm{Al}_{2} \mathrm{O}_{3}$ 基板の位置に水冷銅板を置い て捕集したものである。作製条件は全圧が $14 \mathrm{kPa}, \mathrm{Ar}$ 之 $\mathrm{H}_{2}$ の流量比が $1: 0.4$, 放電出力が $3.5 \mathrm{~kW}$ である。 档徍 $10 \mathrm{~nm}$ 以下の均一な粒于が生成していることがわ かる。 $\mathrm{H}_{2}$ の流量を減少させると精徍がやや增大する傾 向が認められた。

ホットプレス処理の吅熱玔、ケケジュールを Fig. 4 に示す。每時 $350^{\circ} \mathrm{C}$ で鼠鼬し， $1100^{\circ} \mathrm{C}$ で 10 分間プレボ ンディングを行った。これは方しして拉合体構成材料の うちの金牌间志を接合する目的で行った。次に接合温度 $\left(1100^{\circ} \mathrm{C} \sim 1250^{\circ} \mathrm{C}\right)$ まで界温し，30 分間保持したのち降 温した。一万王力は最初 $12 \mathrm{MPa}$ となるように荷重を 加りと，金属の軟化によもなって $900^{\circ} \mathrm{C}$ 付近から低下 しはじめる。 $1100^{\circ} \mathrm{C}$ まで自然低下にまかせたのち，1100 ${ }^{\circ} \mathrm{C}$ 以上では無加厌とした。厈力が初期の值を維持するよ うに荷重を増してゆくと SUS 304 が著しく変形してし まうので，それを避けるため上述のようなスケジュール

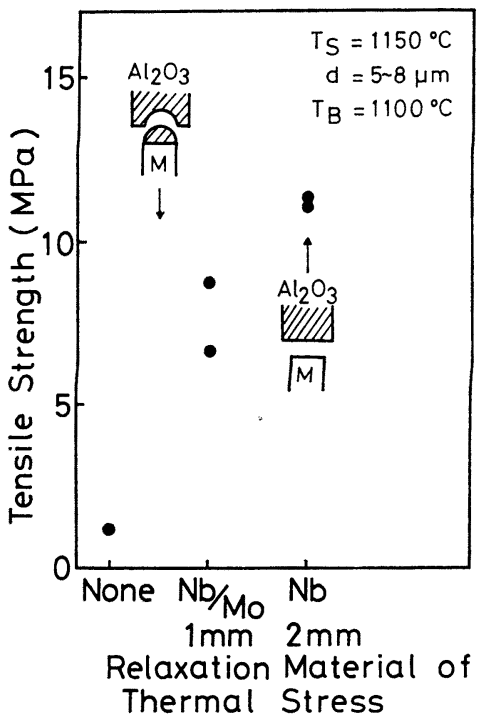

Fig. 5 Dependence of tensile strength on relaxation material of thermal stress. The bonded specimens without a relaxation material of a thermal stress or with that of $1 \mathrm{~mm}$ thick were fractured within the $\mathrm{Al}_{2} \mathrm{O}_{3}$ ceramics, and the specimens with that of $2 \mathrm{~mm}$ thick were fractured along the $\mathrm{Al}_{2} \mathrm{O}_{3} / \mathrm{Nb}$ interface.

を設定した。この処理は $10^{-3} \mathrm{~Pa}$ 台の真壱㕧で行った。 接合体の强度は引張試験機を用いて阔心゙た。引張强度 は試料の破断荷重を破断部の面積で除した值で示す。こ の場合, クロスヘッド速度は $0.5 \mathrm{~mm} / \mathrm{min}$ で行った。

\section{2 結果亡考察}

Fig. 5 亿熱応力緩和材の種類及び厚さと引張強度の 関係を示す。UFP 堆積時の基板温度 $\left(T_{\mathrm{S}}\right)$ は $1150^{\circ} \mathrm{C}$, $\mathrm{UFP}$ 層の厚さ $(d)$ は $5 \sim 8 \mu \mathrm{m}$, 接合温度 $\left(T_{\mathrm{B}}\right)$ は 1100 ${ }^{\circ} \mathrm{C}$ である。応力緩和材の厚さの増加にともなって強度が 增玑しているととがわかる。破断の様子を見ると，嬮さ が 0 及び $1 \mathrm{~mm}$ の時には $\mathrm{Al}_{2} \mathrm{O}_{3}$ 内で破断が起こってお り，充分に応力が緩和されていないことがわかる。な お， $1 \mathrm{~mm}$ の時は $\mathrm{Nb}$ 単層よりも緩和効果の大きい $\mathrm{Nb} /$ Mo 積尿 (各々の厚さは $0.5 \mathrm{~mm}$ ) 構造とした ${ }^{8}$ 。厚さ 2 $\mathrm{mm}$ の $\mathrm{Nb}$ を単独で用いた時には破断は $\mathrm{Al}_{2} \mathrm{O}_{3}$ と $\mathrm{Nb}$ (UFP 層) の界面で起こっており，応力が緩和されてい るととがわかる。Mo との積層構造にすることによって， 全厭を $2 \mathrm{~mm}$ より薄く（ただし $1 \mathrm{~mm}$ より曆い）する こと屯可能と思われるが，本実験の目的からはずれるの で，これ以降の実験では応力緩和材として厚さ $2 \mathrm{~mm}$ の $\mathrm{Nb}$ を単独で挿入することにした。

Fig. 6 に Nb UFP 層の厭さと引張強度の関係を示 す。基板温度は $950 \sim 1050^{\circ} \mathrm{C}$, 接合温度は $1200^{\circ} \mathrm{C}$ であ 


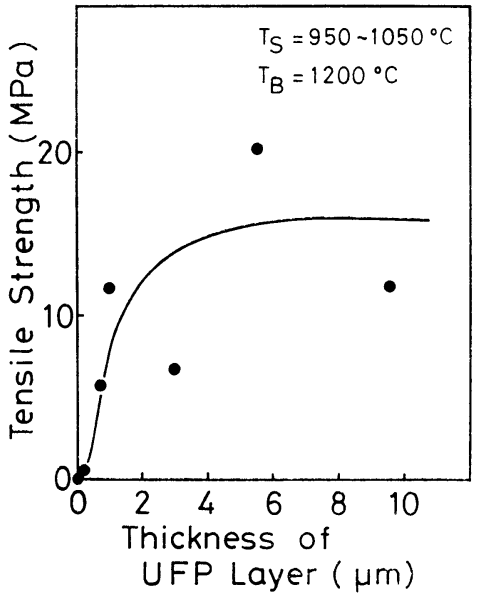

Fig. 6 Tensile strength as a function of $\mathrm{Nb}$ UFP layer thickness.

る。厚さは付着重量を比重と付着部の面積の積で除した 值で示している。いいかえれば，充填率を $100 \%$ とした 時の $\mathrm{Al}_{2} \mathrm{O}_{3}$ 表面から $\mathrm{Nb} \mathrm{UFP}$ 層表面までの平均の距 離を表わしている。厚さが $1 \mu \mathrm{m}$ 以上になると急激に強 度が高くなり， $5 \mu \mathrm{m}$ 以上で飽和する傾向が見られる。 簡䉓なモデルを考えてみるとわかるように, $\mathrm{Al}_{2} \mathrm{O}_{3}$ の表 面粗さによる突起が Nb UFP によって完全におおいつ くされるには $R_{\max }$ の $1 / 2$ の厚さが必要である。実験 に用いた $\mathrm{Al}_{2} \mathrm{O}_{3}$ の $R_{\max }$ は 4 $8 \mu \mathrm{m}$ であることから， $\mathrm{Al}_{2} \mathrm{O}_{3}$ の表面粗さによる突起が $\mathrm{Nb}$ UFP によっておお いつくされた時高強度になると考えられる。

Fig. 7 にb UFP 堆積時の $\mathrm{Al}_{2} \mathrm{O}_{3}$ 基板温度と引 張強度の関係を示す。UFP 層の厚さは $5 \sim 12 \mu \mathrm{m}$, 接 合温度は $1250^{\circ} \mathrm{C}$ である。基板温度が $750^{\circ} \mathrm{C}$ 以上になる と急激に強度が高くなり, $800^{\circ} \mathrm{C}$ 以上では飽和する傾向 が見られる。堆積した UFP 層を目視観察すると，基板 温度が $800^{\circ} \mathrm{C}$ 以上では連続膜状，それ以下では粉状を呈 していた。このてとから，堆積時に充分燒結していない 粉状の UFP 層は大気中では酸化しやすく，そのため活 吽を失って，UFP 層として用いた接合体の強度が低く なるものと思われる。なお，通常の方法で作製し，表面 に酸化層を形成して安定化した $\mathrm{Nb}$ UFP $\mathrm{Al}_{2} \mathrm{O}_{3}$ の 接合面に塗布することによって UFP 層を形成したもの は，同一処理条件下において全く接合がなされなかっ た。このことからもUFP 眉の酸化状態は接合強度に大 きく影響していると考えられる。

Fig. 8 に Nb UFP の堆積速度と引張強度の関係を 示す。基板温度は $950 \sim 1050^{\circ} \mathrm{C}$, UFP 層の厚さは $5 \sim 12$ $\mu \mathrm{m}$ である。接合温度が $1100^{\circ} \mathrm{C}$ の時には強度は低く, 堆積速度には依存しない。按合温度が $1200^{\circ} \mathrm{C}$ 及び 1250

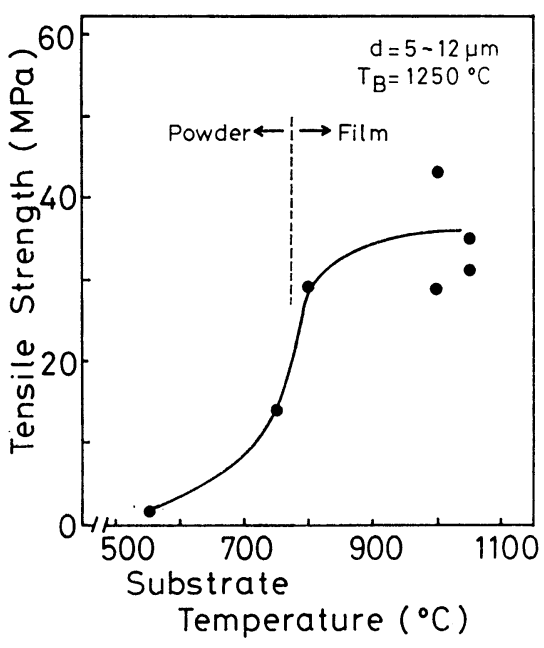

Fig. 7 Tensile strength as a function of substrate temperature.

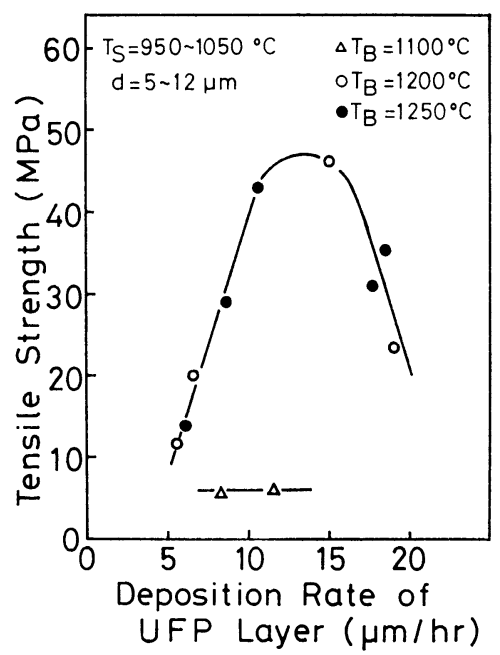

Fig. 8 Tensile strength as a function of $\mathrm{Nb}$ UFP deposition rate.

${ }^{\circ} \mathrm{C}$ の時には堆積速度に対して強度が最大值をむつよう な曲線となっている。この理由については明らかではな いが，Nb UFP 層の酸化状態と関係があるのではない かと考えている。 $\mathrm{Nb}$ がわずかに酸化している $\mathrm{NbO}_{x}$ という相は $\mathrm{Al}_{2} \mathrm{O}_{3}$ との格子整合性がよいという報告が ある9)。最終的にこのような相が生じるためには $\mathrm{Nb}$ UFP 首が適当な酸化状態になっていることが必要で, 酸化の度合いが大きすぎてむ小さすぎてむよくないと考 えられる。Nb UFP 層が酸化する要因としては, 気相 中での残留酸素との衝突及び堆積後の $\mathrm{Al}_{2} \mathrm{O}_{3}$ 基板から の酸素の拡散が考えられるが，いずれも堆積速度が遅い 
ほど酸化を進行させる方向に㗢く。したがって適当な堆 積速度の時に最も強度が高くなると考えられる。なお， 接合温度が $1200^{\circ} \mathrm{C}$ と $1250^{\circ} \mathrm{C}$ では強度に差はなく，得ら れた最大強度は $46 \mathrm{MPa}$ であった。これは，HIP を用 いて $1300^{\circ} \mathrm{C}, 100 \mathrm{MPa}$ で接合した（UFP層を用いな (）試料で得られた值 $(60 \mathrm{MPa})^{8)}$ に匹敵する。

以上のように, $\mathrm{Nb} \mathrm{UFP}$ を $\mathrm{Al}_{2} \mathrm{O}_{3}$ の接合面にその 場で堆積させる方法で接着層を形成するととによって， SUS 304 との固相接合が $1200^{\circ} \mathrm{C}$, 無加圧（ただし， 900 ${ }^{\circ} \mathrm{C}$ では $12 \mathrm{MPa}$ ) 下の処理でできた。接合強度はUFP 堆積時の基板温度及び堆積速度に大きく依存し, UFP 層の酸化状態と関係があることが示唆された。

\section{4. その他の応用}

$\mathrm{Al}_{2} \mathrm{O}_{3}$ と SUS 304 の固相接合において, UFP 層を挿 入するととの有効性が認められた。現在，他のセラミッ クスと金属あるいはセラミックス同志の接合への応用を 試みているが，乙こでは窒化ケイ素 $\left(\mathrm{Si}_{3} \mathrm{~N}_{4}\right)$ 同志の接合 についててれまでに得られている結果を簡単に述べる。

$\mathrm{Si}_{3} \mathrm{~N}_{4}$ は耐熱性構造材として期待されるセラミックス であるが(0)，母材並の強度，耐熱性を有する接合体を得 るには，接合層の主成分が $\mathrm{Si}_{3} \mathrm{~N}_{4}$ であるととが必要で ある。

作製した接合体の断面図を Fig. 9 亿示す。 $\mathrm{Si}_{3} \mathrm{~N}_{4}$ は $\mathrm{Al}_{2} \mathrm{O}_{3}$ と $\mathrm{MgO}$ を燒結助剂とした常圧焼結体である。 $\mathrm{UFP}$ 層は，ガス中蒸発法で作製した $\mathrm{Si}_{3} \mathrm{~N}_{4} \mathrm{UFP}$ をア セトン中に分散し，それを塗布，乾燥させるととによっ て形成した。接合は, 1 気圧の $\mathrm{N}_{2}$ 霧囲気中で, $15 \mathrm{MPa}$ の加圧下, $1500^{\circ} \mathrm{C}$ の温度で 30 分間保持するととによっ て行った。乙れは $\mathrm{Si}_{3} \mathrm{~N}_{4}$ 母材が変形しない上限の条件で あった。

Fig. 10 亿 $\mathrm{Si}_{3} \mathrm{~N}_{4}$ UFP 作製装㯰の概略図を示ず。 作製方法はアーク放電を利用した反応性ガス中蒸発法で ある。放電ガスは $\mathrm{Ar}$ と $\mathrm{H}_{2}$ の混合ガスで, 反忍ガス として $\mathrm{NH}_{3}$ を捕集板付近に流した。捕集板温度は 500

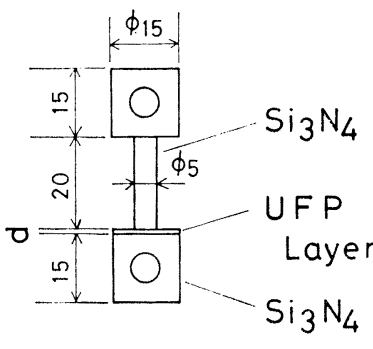

$(\mathrm{mm})$

Fig. 9 Cross-sectional view of bonded specimen.
${ }^{\circ} \mathrm{C}$ に保持した。蒸発源には Si-Mo 合金を用い，蒸気厈 差によって Si のみを蒸発させた。全王を $45 \mathrm{kPa}, \mathrm{Ar}$, $\mathrm{H}_{2}$ 及び $\mathrm{NH}_{3}$ の流量をそれぞれ $2 \mathrm{l} / \mathrm{min}, 1 \mathrm{l} / \mathrm{min}$ 及 び $2 l / \mathrm{min}$ とし，アーク放電出力を $3.5 \mathrm{~kW}$ とした。 EPMA による組成分析の結果, UFP 中の窒素含有量 は化学量論比に対して $90 \%$ 以上であり，また $5 \mathrm{wt} \%$ 前後の酸素を含むことがわかった。TEM 像から, 平均 粒径は $30 \mathrm{~nm}$ と判定された。

接合体の引張強度は70 MPa であった。比較のため に，同一処理条件下で，母材間に何む插入しないむの及 び市販の $\mathrm{Si}_{3} \mathrm{~N}_{4}$ 微粉末 (平均粒径 $200 \mathrm{~nm}$, 酸素含有量 $2 \mathrm{wt} \%$ ）を挿入したものを作製したが，それらの引張强 度はいずれあ $15 \mathrm{MPa}$ であった。

Fig. 11 EPMA で測定した接合界面近傍の元素 濃度変化を示す。測定は分析径 $1 \mu \mathrm{m}$, 加速電圧 $20 \mathrm{kV}$ で行った。接合層で $\mathrm{Al}$ 及び $\mathrm{Mg}$ の濃度が高くなって

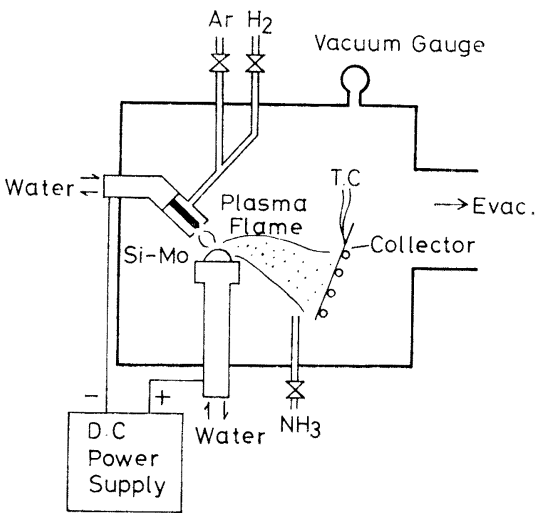

Fig. 10 Schematic diagram of the apparatus for $\mathrm{Si}_{3} \mathrm{~N}_{4}$ UFP preparation.

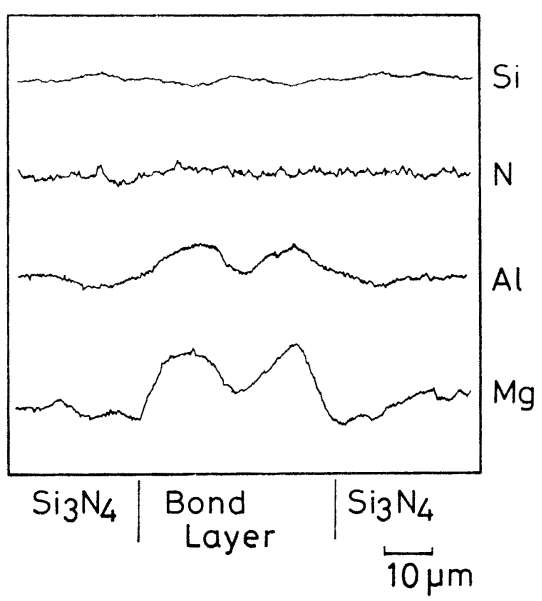

Fig. 11 Concentration profile across the bonded interface of specimen measured by EPMA. 
おり, $\mathrm{Si}_{3} \mathrm{~N}_{4}$ 时材中の助剂成分が拡散したもの之思われ 万。この処理条件 $\left(1500^{\circ} \mathrm{C}, 15 \mathrm{MPa}\right)$ 下では通学 $\mathrm{Si}_{3} \mathrm{~N}_{4}$ は巣味では燒結せず，烧結助剤が必要である。本尖験で は，UFP 層に母材からその燒結助剤成分が昖散するこ とによって，低温下での烧結と按合が可能となったもの と思われる。

以上のように, $\mathrm{Si}_{3} \mathrm{~N}_{4}$ の接全に扔いても UFP 層を雨 入することは効果があることがわかったが，按合強度は まだ允分とはいえず，今後の課題である。

\section{5. おわりに}

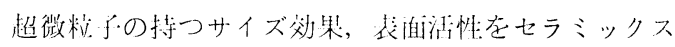
の按合に利用すると, 従来考えられなかった低温低生下 での固相接合が可能となる。一方，その表面活性ゆえに 利用する際には特別な工夫が必要となる場合がある。 $\mathrm{Nb}$ UFP では, 加熱された $\mathrm{Al}_{2} \mathrm{O}_{3}$ の按合面にその場で 非棈することによってはじめて本来の特性が発兒できて いる。

セラミックスの利用分野は今後ますます広がってゆく むのと思われる。そのキーテクノロジーが接合技術だと いわれている。ここで示された方法はその原理から，む
らゆるセラミックスと金風むるいはセラミックス同志の 接合に忍朋问能であり，令後の㘿開が期待される。

\section{文献}

1) 大箖 明：忉料技術 3.87 (1985).

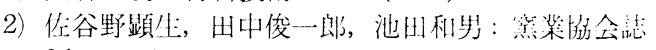
94, 108 (1986).

3) R. J. Bondley: "Metal-Ceramic Brazed Seals", Electronics 20, 97 (1947).

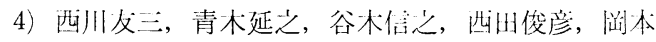

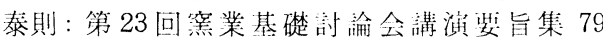
$(1985,1)$.

5) 阔本平, 湉克昭: IONICS $7(1985,7)$.

6) S. Kashu, M. Nagase, C. Hayashi, E. Kamijo and T. Nishimoto: Proc. 4th Vacuum Metallurgy Conf. 269 (1975).

7) H. Kondo, T. Funayama and A. Itoh: Proc. Intern. Ion Engineering Cong. 1407 (1983).

8) K. Suganuma, T. Okamoto, M. Koizumi and M. Shimada: J. Nucl. Mater. 133 \& 134, 773 (1985).

9) S. Morozumi, M. Kikuchi and T. Nishino: J. Mater. Sci. 16, 2137 (1981).

10）林 安茂, 今井吉彦：金属 56 (7), 33 (1986). 